\title{
Board Leadership, Chief Executive Officer Optimism and Firm Innovation
}

\author{
Joel Tuwey ${ }^{1 *}$, Vincent Ngeno ${ }^{2}$ \\ 1, 2 Moi University, Kenya \\ * Corresponding author: joeltuwey@yahoo.com
}

\begin{abstract}
Article History
Received 2019-09-06

Revised 2019-09-30

Accepted 2019-10-01

Published 2019-10-03
\end{abstract}

\section{Keywords}

Board Leadership

Board Member Openness

Board Member Independence

CEO Optimism

Firm Innovation

\section{How to cite?}

Tuwey, J., Ngeno, V., \& Tarus, D. (2019). Board Leadership, Chief Executive Officer Optimism and Firm Innovation. SEISENSE Journal of Management, 2(6), 1-16. doi: $10.33215 /$ sjom.v2i6.221

\begin{abstract}
Purpose- Following the resource dependence and optimism theory, the study explored whether Chief Executive Officer (CEO) optimism moderates the link between board leadership and firm innovation in the financial sector.

Design/Methodology- 130 financial institutions in Kenya were surveyed using cross-sectional and explanatory designs. Hypothesis testing utilized both moderated hierarchical regression models and mod-graphs.

Findings- The results revealed that the board member's openness and independence positively influence firm innovation. The moderated hierarchical regression results and figures in the modgraphs reveal that $\mathrm{CEO}$ optimism enhances the association between the board member's openness, independence, and firm innovation.

Practical Implications- The results suggested that for financial institutions to be innovative, board members should be open to each other in terms of the private ideas as well as being independent about decisions made to spur the growth of the firms. Additionally, such boards should appoint CEOs who are optimistic about being innovative.
\end{abstract}




\section{Introduction}

Innovation is a vital element for competitiveness and the continued existence of the firm (Cohen, Diether, \& Malloy, 2013). Drawing from the scholarly work of Schumpeter in 1934, innovation is seen as the "creative destruction by an entrepreneur." This indicates that innovation is an idea or practice that is perceived as new by an individual or institution (Wang, 2009). Innovation is a peculiar way to create or improve a new product or service (Merton, 1995) in any sector; however, the distinctive nature and purpose of innovations denote that it may vary across sectors (Anderloni, Llewellyn, \& Schmidt, 2009). Thus, in the financial sector, innovation is the conception of new financial products, services, and processes (Lerner $\&$ Tufano, 2011). In particular, it is a process that involves the creation, promotion, and acceptance of products, services, platforms, and methods or enabler of technologies that present new ways and approaches of carrying out and delivering financial transactions (Khraisha \& Arthur, 2018).

Although existing scholars have indicated that leadership is key for innovation (Capozzi, 2010), they are skewed to CEO leadership (Makri \& Scandura, 2010); (Sunder, Sunder, \& Zhang, 2017) to the exclusion of board leadership, yet boards engage in the formulation and implementation of strategies of the firm. Essentially, literature shows that boards provide important resources (Pfeffer \& Salancik, 1978) that support strategic activities. Besides, they are responsible for setting objectives, and priorities (Xie \& O'Neill, 2013) provide strategic directions and approve innovation proposals (Tuwey \& Tarus, 2016); (Deschamps \& Nelson, 2014) and nurtures innovation (Yar Hamidi \& Gabrielsson, 2014). Despite the substantial role that board members play in strategy formulation and implementation, how board leadership influences strategic activities such as innovation has not been sufficiently explored (Charan, Carey, \& Useem, 2013); (Iren \& Tee, 2018); (RegueraAlvarado \& Bravo, 2018) particularly in the financial sector. Hence, we intend to establish how board leadership influences innovation in Kenya's financial sector.

Additionally, to complement on boards contribution to strategic activities such as innovation, the study incorporated CEO leadership trait (Hambrick, 2007); (Finkelstein, Cannella, Hambrick, \& Cannella, 2009) beyond the leadership of the board. Earlier studies have documented that leadership traits shapes how CEOs make decisions in different situations in the firm (Hogan \& Kaiser, 2005); (Graham, Harvey, \& Puri, 2013). Further, it has indicated how CEOs perceive their influence on strategic decisions and outcomes such as innovation (Langabeer \& Yao, 2012); (Zhang, Ou, Tsui, \& Wang, 2017). Thus, the study examined an important trait that influences strategic decision making: CEO optimism. This trait was hypothesized to moderate the relationship between board leadership and firm innovation.

\section{Literature Review}

\section{The Kenyan Context}

This research extends the literature on corporate boards and innovation by focusing on a developing country; Kenya. However, most studies have delved on this subject in developed countries. Indeed, Kenya is the appropriate choice for the study because of its innovative capabilities in the world and the Sub-Saharan region (Dutta, Lanvin, \& Wunsch-Vincent, 2018). Also, Kenya is ranked $78^{\text {th }}$ in the world and third in the Sub-Saharan region after South Africa and Mauritius. Additionally, in East Africa region the sector is the largest with a total asset base of 4.27 trillion, total loans of 2.49 trillion and deposit base of 3.16 trillion (Kimenyi, Mwega, \& Ndung'u, 2015).

The financial sector in Kenya is comprised of 13 Microfinance, 40 Commercial Banks, and 166 Savings Credit and Cooperative Societies that are all registered as deposit-taking institutions under the Central Bank of Kenya. The Central Bank Act, and other prudential guidelines, company's Act, banking Act, microfinance Act, and SACCO Societies Act are some of the laws that ensure efficient operations. In 2015, the central bank established 
the corporate governance guidelines through capital market authority (CMA). More importantly, these guidelines exhibit features that are applicable in developed countries. The guidelines outline how boards are organized, configured, and the role that board members play in executing strategic activities of the firm. Most financial institutions in Kenya have incorporated corporate governance guidelines such as appointing the board of directors to assist in the corporate leadership of financial institutions.

The financial sector is characterized by heavy reliance on Information and Communication Technology and a supportive legal framework (Ngugi, Pelowski, \& Ogembo, 2010); (Tarus \& Sitienei, 2015) that has allowed innovation to flourish in the finance sector. Importantly, the finance sector has partnered with mobile network operators such as Safaricom and Airtel to allow financial transactions to be effected using mobile phones. As a result, the Central Bank of Kenya drafted a law to legalize mobile money transfers in the National Payment System Act of 2011 and 2014, respectively. Kenya is the first country to allow payment systems using mobile phones (Hughes \& Lonie, 2007) and continues to develop innovations in the finance sector that influence how bank customer services and transactions are handled. The most popular innovation that has changed the financial landscape in Kenya is the mobile and agency banking (Muthiora, 2015).

According to the Communications Authority of Kenya statistics of 2018, 80\% of the Kenyans use mobile banking services with M-PESA leading at $70 \%$ of the total mobile money transfers (Lepoutre \& Oguntoye, 2018). "M-PESA" is a blend of two words, "M" for "Mobile" and a Swahili word "PESA," thus, mobile cash" (Ngugi et al., 2010)., the technology allows people to deposit, send and withdraw cash using a mobile phone. Since the emergence of "M-Pesa" technology, several other innovations such as M-shwari, KCB-Mpesa, M-kesho, M-pawa, Fuliza, Kopesha, MCo-op Cash, M-Kopo and Chapaa Popote have continued to be witnessed (Chipeta \& Muthinja, 2018), these innovations allow customers to send, withdraw and borrow cash, pay insurance premiums, undertake point-of-sale transactions and payment of utility bills such as school fees, electricity, and water bills, government services, retail outlets, and air ticketing among others (Chipeta \& Muthinja, 2018); (Lashitew, van Tulder, \& Liasse, 2019). As such, consumers can access financial services conveniently at a cheaper cost (Jack \& Suri, 2014); (Munyegera \& Matsumoto, 2016) and by a click of a button at the comfort of their homes or workplaces without going to the bank (Jack \& Suri, 2011). Also, customers can save and still grow their loan credibility.

Notably, to craft such innovations, it requires a strategic approach, an in-depth information search, critical thinking, and open-mindedness, especially from those entrusted with leadership and governance. In this regard, board members aid in strategic decision-making by advising the CEOs on the best alternative to pursue in a dynamic and competitive environment such as the Kenyan context. In particular, board members should be open and independent to tap key resources that are required for innovations. Basically, as decision-makers in financial institutions, board members and the CEOs play an important role in providing direction specifically on strategic decisions such as those related to innovations.

In addition to the understanding of how boards influence innovation, this paper also investigates whether CEO trait (Hambrick, 2007); (Chatterjee \& Hambrick, 2011) plays a role in the strategic decision-making and outcomes of the firm such as innovation. Extant studies have indicated that CEO optimism is an important trait that influences strategic decisions (Langabeer \& Yao, 2012), thus, concerning this trait, it may influence how corporate boards engage in strategic decisions of the firm such as innovation. Although the board of directors may provide useful contacts and networks that support innovation (Nicholson \& Kiel, 2004), the decision to tap on such resources is largely dependent on the character of the CEO (Finkelstein et al., 2009). According to the theory of optimism (Scheier \& Carver, 1985), individuals who are optimistic hold the view that positive than negative outcomes will occur in the future and that value is attached to the expected outcome. Therefore, an optimistic CEO tend to attach value and exude confidence (Harpaz-Itay \& Kaniel, 2012) to achieve a given strategic activity such as innovation, thus, may inspire board members by sharing such a positive 
vision and display a passionate interest to achieve it. Hence, this paper includes CEO optimism as a moderator in the relationship between board leadership and firm innovation.

\section{Board Member's Openness and Firm Innovation}

Board member's openness is defined as the flow of information between board members themselves and top management teams (TMTs), including the CEO (Gabrielsson \& Huse, 2005). Board openness is a conduit through which the board functions effectively (Sonnenfeld, 2002) and a key aspect of board leadership that allow the board of directors engages openly and widely for quality and better decisions (Sun, Zhu, \& Ye, 2015). Board members' ability to ask questions, challenge each other as well as seeking views and opinions from each other in the boardroom adds value to the firm (Forbes \& Milliken, 1999) because in the process of such debates and dialogues, new perspectives that are useful in supporting innovative activities are likely to be tapped (Leblanc \& Gillies, 2005). Moreover, open boards stir debates which let board members expend their skills to generate new ideas and suggestions that are helpful for innovation (Jehn, 1995) when board members are open, they can ask questions to each other and the CEO on those activities that are strategic to the firm.

Consequently, openness and arguments on the board may allow directors to generate new ideas and suggestions that support innovation (Sun et al., 2015). Thus, board members can offer advice on firm innovativeness based on their private knowledge and ideas while accepting that they can be wrong in their deliberations. Thus, the study hypothesized that:

$\mathrm{H}_{\mathrm{o} 1}$ : Board members' openness positively influence firm innovation

\section{Board Member's Independence and Firm Innovation}

In Kenya, board members for financial institutions are categorized into executive and non-executive directors. Board independence represents the number of external directors who do not have any material association with the firm except that of the position of the firm, large shareholders or the CEO (Abebe \& Myint, 2018). So, independent board members are expected to be objective and unbiased as regards to the board decisions. Drawing from the resource dependence theory (Pfeffer \& Salancik, 1978), independent board members can control and advise the executives (Hillman \& Dalziel, 2003), secure resources that are financial and offer nonfinancial resources such as knowledge, contacts, and legitimacy (Drees \& Heugens, 2013) that may be helpful to enhance firm innovativeness. Existing work is mixed on how board members independence enhance firm innovation. For instance, some scholars found a positive association (Balsmeier, Fleming, \& Manso, 2017); (Iren \& Tee, 2018); (Helmers, Patnam, \& Rau, 2017); (Oh \& Barker III, 2018), others showed no association (Kor, 2006). In line with these, some evidence shows that the strict role of independent board members reduces the appetite to innovate by instilling apprehension of being penalized for unsuccessful innovation and thus CEOs may be reluctant to innovate (Manso, 2011); (Faleye, Hoitash, \& Hoitash, 2011). Although the empirical evidence reviewed are mixed, this study presents the view that in addition to their monitoring role, a board with directors able to link the firm to important contacts and help them secure resources that necessary for firm innovation. This is because they have accumulated market information and valuable resources that are adequate for firm innovations (Pugliese, Minichilli, \& Zattoni, 2014). Thus, it was hypothesized that:

$\mathrm{H}_{\mathrm{o} 2}$ : Board members' independence positively influence firm innovation

\section{Moderating Role of CEO Optimism}

Optimism is a disposition where an individual expects better than bad things to happen in the future (Langabeer \& DelliFraine, 2011); (Scheier \& Carver, 1985). Optimism is a critical personality that has received substantial research interest, especially about the strategic decision making that a CEO may undertake. Extant literature shows that optimists, as opposed to pessimists, are resilient, have a positive outlook of the world, actionoriented, inspire others by sharing a positive vision and display a passionate interest to achieve that vision 
(Carver \& Scheier, 2014); (Chiesi, Galli, Primi, Innocenti Borgi, \& Bonacchi, 2013). They are ready to pursue goals in complex and unpredictable situations because of the conviction that good than bad is bound to ensue to them in future (Trevelyan, 2008). Moreover, optimists foresee greater opportunities in what they do (Levinthal \& March, 1993) and are excited to face challenges in complex scenarios (Seligman, 2006).

Although board members bring into the firm essential resources, a firm's ability to tap and use these resources effectively largely depends on the CEO (Finkelstein, 1992). This is because the CEO pursue firm activities on day to day basis, whereas the board members' involvement is occasional. Thus, the CEO can provide allinclusive information that may be used by the directors (Adams \& Ferreira, 2007). According to the theory optimism (Scheier \& Carver, 1985), the anticipated positive outcomes depend on the value attached to the goal intended to be achieved and the confidence portrayed (Harpaz-Itay \& Kaniel, 2012) and the behavior of others (Gallagher \& Lopez, 2009). Ordinarily, board actions influence the chief executive's behavior, and it is inherent for the CEO to align their expectations to directions given by the board to give feedback and progress (Weill \& Ross, 2004). However, the personality of the CEO may affect the decisions of the board (Chatterjee \& Hambrick, 2007). For instance, CEO optimism may influence strategic decisions that the board makes to ensure firms remain competitive (Langabeer \& DelliFraine, 2011); (Langabeer \& Yao, 2012). Despite this perception, optimism at the CEO level is an important trait, though, has largely been ignored in the board - innovation relationship (Langabeer \& Yao, 2012).

Based on the resource dependence theory (Pfeffer \& Salancik, 1978), directors bring into firm technical resources that are used to develop new products and services. One important resource is their openness in terms of their private ideas and suggestions they propose in the board meetings. Constant interactions and dialogues among board members enhance effectiveness in the performance of board tasks because they can ask questions, challenge one another and seek views from each other (Sun et al., 2015) that might be used to tap information or ideas supportive of innovations (Charan, 2005). In other words, a board that is composed of members who are open and willing to share their ideas are more likely to generate ideas that may be useful for innovations. The extent to which board members are allowed to ask questions to each other and about the firm (Gabrielsson, Huse, \& Minichilli, 2007) fosters trust and confidence that they can offer strategic advice based on their private knowledge, ideas, and views. Besides, according to the theory of optimism (Scheier \& Carver, 1985), human behavior can be explained in terms of goals to be achieved. As such, how individuals pursue and achieve goals is largely dependent on their positive expectations. Therefore, when CEOs are highly optimistic, board members are likely to be more open, interactive and willing to offer wide perspectives of information because such CEOs tend to envision greater opportunities for the firm (Fama \& Jensen, 1983; Levinthal \& March, 1993). The optimism of the CEO inspires open discussions and deliberations among board members on ideas that are innovative oriented. Hence, the study proposed that:

$\mathrm{H}_{03 a}$ : CEO optimism positively moderates the relationship between board member's openness and firm innovation.

Previous literature indicates that independence enables board members to make objective decisions while executing strategic decisions and the function of overseeing the CEOs (Fama \& Jensen, 1983). A new strand of literature has reiterated that advising function of independent directors is important for the strategic process of the firm (Faleye et al., 2011). This is because directors may have the experience, expertise, and a blend of networks that allows them to provide resources and advise required for strategic activities like innovation. Because independent directors do not have close relations with the firm or the CEO, they pursue interests that would benefit the firm and its relevant stakeholders in the long term. Particularly, directors decisively prioritize and provide strategic advice functions such as innovation that may enable firms to be competitive and sustainable (Kor, 2006). As a result, CEOs may commit enough of their time and efforts to innovate. When CEOs are optimistic, they overrate their expectations (Zhao \& Ziebart, 2017) on innovation and ignore the 
existing realities of the market conditions and developments (Langabeer \& DelliFraine, 2011). However, this level of optimism among the CEOs may weaken the strength of an independent board composed of members who are more experienced to engage in firm innovation. In other words, overly optimistic CEOs makes board members reluctant on putting more efforts on innovation since the independence of the board enables them to effectively evaluate whether innovation proposals are feasible or not rather than just positive expectations from optimistic CEOs. Thus, it was anticipated that at a given level of CEO optimism, the enthusiasm to innovate among independent board members decreases. As a result, the study purposed to test $\mathrm{H}_{\mathrm{o} 3 \mathrm{~b}}$;

$\mathrm{H}_{\text {озь }}$ : CEO optimism negatively moderates the relationship between board member's Independence and firm innovation.

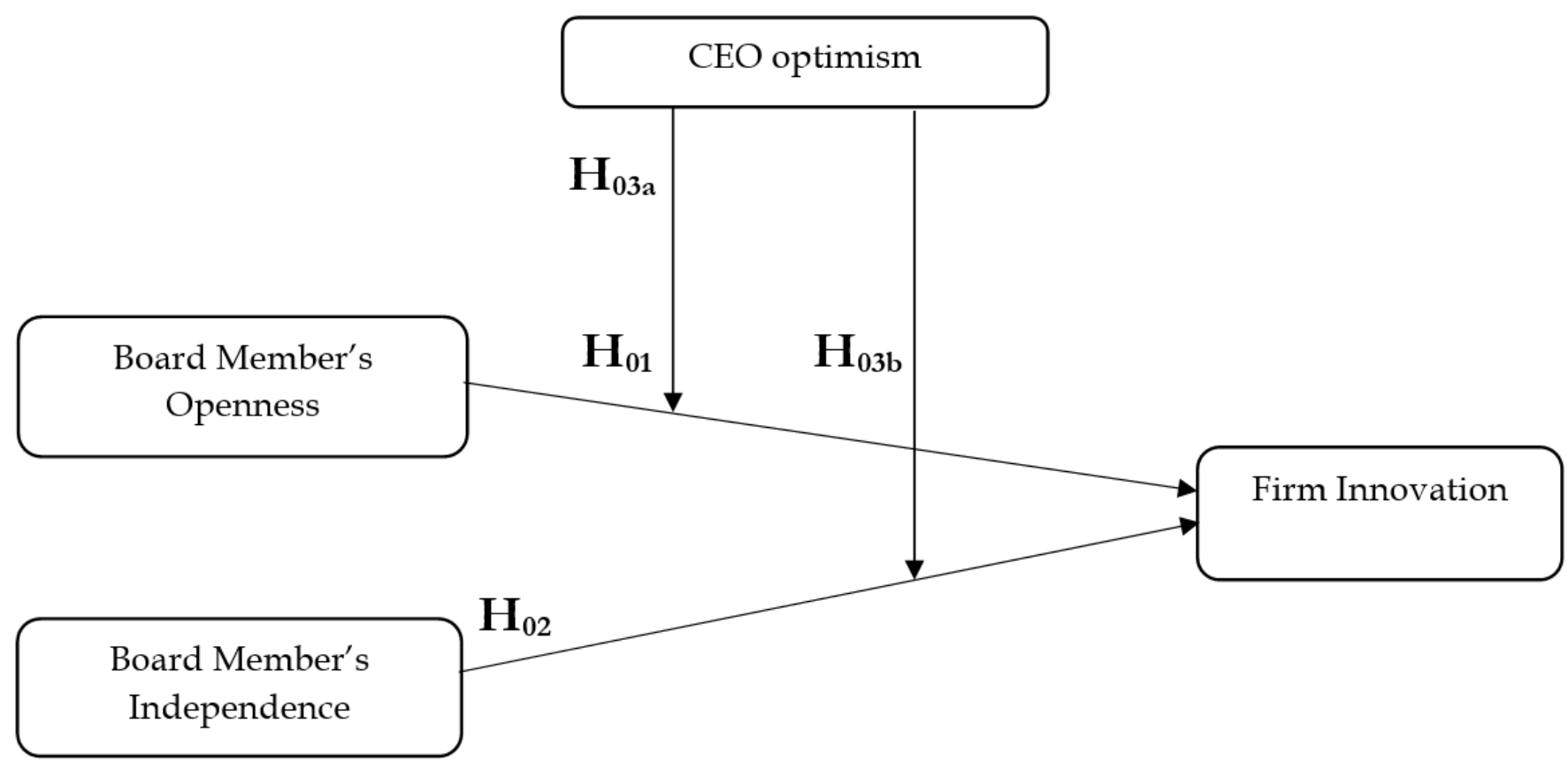

Figure 1 - Conceptual framework

\section{Theoretical Review}

This paper drew its arguments from resource dependence (Pfeffer \& Salancik, 1978) and optimism (Scheier \& Carver, 1985). The resource dependence theory posits that boards are a conduit for handling external dependence and linking the firm with its environment, thus reducing uncertainty (Pfeffer \& Salancik, 2003).

Further, they noted that "When firms hire a director into the board, it anticipates that such a director to support the firm, be a concern with its challenges and try to solve it." Board members bring into the firm their technical competencies, professional contacts, and networks to influential funders and provide strategic direction of the firm (Brown, 2005). Specifically, apart from executing their monitoring or control roles in organizations, the theory argues that board members support and provide key resources such as openness, and independence that may influence decisions of the firm (Dalziel, Gentry, \& Bowerman, 2011). Further, board capital outlines how directors control and offer strategic advice, new insights (Haynes \& Hillman, 2010) and resources about innovation (Chen, 2014). Indeed, the resource provision role is a critical component of innovation. Firms may experience problems in developing effective innovation capabilities without strategic guidance and adequate resources (Hillman \& Dalziel, 2003), hence, from the resource dependence perspective, board members are 
valuable in terms of providing their technical competences and linking the firm with the external environment. As such, it is possible for the directors who are open and independent to identify innovation opportunities and offer strategic guidance on innovation.

\section{Research Methodology}

The target population was 219 financial institutions in Kenya. The financial sector was appropriate because of an elaborate and sound framework of governance and the unique levels of innovations (Ngugi et al., 2010); (Daily, Dalton, \& Cannella Jr, 2003; Giorgis Sahile, Tarus, \& Cheruiyot, 2015). The Yamane (1973) formula was used to arrive at a sample size of 183 firms as follows;

$n=\frac{\mathrm{N}}{1+\mathrm{N}_{\mathrm{e}^{2}}}$ Where: $\mathbf{n}=$ Sample size $; \mathbf{N}=$ Total population size; $\mathbf{e}=$ the error of Sampling $(0.03)$

$n=\frac{219}{1+219(0.03)^{2}}=183$ financial institutions

The primary data was collected using questionnaires administered to both the CEO and two heads of department in each firm. A total of 549 questionnaires were distributed to the 183 firms, out of which 465 questionnaires were returned, but only 390 questionnaires for 130 were used for analysis as 75 questionnaires were excluded from the analysis. All these were equivalent to a response rate of $71.04 \%$. The higher response rate was due to follow up by researcher. CEOs were expected to respond to board leadership aspects and firm innovation by the position they hold that exposes them to board and day to day activities and also gave a selfreport on their level of optimism. Also, it is normally difficult to access board members (Daily, Dalton, \& Cannella Jr, 2003). Additionally, to mitigate the self-report bias, the CEO to respond on behalf of the directors and the two heads of departments to assess the trait of optimism among the CEOs.

\section{Reliability and Validity}

Validity of the items in the questionnaire was guaranteed by adapting the measurement scales previous tested by different scholars (Calantone, Cavusgil, \& Zhao, 2002; Lin, 2007); (Huse, 2005); (Sellevold, Huse, \& Hansen, 2007); (Scheier, Carver, \& Bridges, 1994); (Flynn, Huo, \& Zhao, 2010); (Li, Huang, \& Tsai, 2009); (Jiang, Wang, \& Zhao, 2012); (Anderson \& Reeb, 2003). Cronbach's alpha was employed to ensure the reliability of the research instrument. The instrument was reliable for data collection as all the Cronbach alpha values were $>.70$ (Sekaran \& Bougie, 2013). Moreover, factor analysis was performed to check for construct validity. The analysis showed that firm innovation generated a one-factor solution with an Eigenvalue of 2.568 and item loadings greater than 0.5 (F. Hair Jr, Sarstedt, Hopkins, \& G. Kuppelwieser, 2014). Equally, all independent variables and a moderator all had Eigenvalues $>1$ and factor loadings of above 0.5 (F. Hair Jr et al., 2014). This confirmed the existence of convergent validity.

\section{Measurement of the Variables}

The study adopted the previously validated scales. However, the measures were modified to ensemble the present study. The study employed 5 point Likert-type scales, rated (1) for strongly disagree to (5) strongly agree. On firm innovation, six-item scales were adapted from (Calantone et al., 2002) and Lin, (2007). The used four questions to measure board members openness as validated by (Huse, 2005) and six questions that measured board members independence were adapted from (Sellevold et al., 2007). CEO optimism was adapted from (Scheier et al., 1994) based on the revised Life Orientation Test (LOT-test) measuring CEO optimism. The study also controlled for firm age, size, and financial performance for their potential influence on firm innovation. All the six questions measuring financial performance were adapted from (Flynn et al., 2010) and (Li et al., 2009). Firm size was measured using the number of employees, in five categories, with $1=1-300$ employees, $2=301-600$ employees, $3=601-900$ employees, $4=901-1200$ employees and $5=$ above 1200 
employees (Jiang et al., 2012). Age was measured using years that firms have existed (Anderson \& Reeb, 2003) in three categories, with 1 = below five years, $2=$ between $5-10$ years, $3=$ above 10 years.

\section{Regression Models}

To test the hypotheses, a hierarchical regression analysis was conducted. Before performing the analyses, all the variables were standardized as z-scores to test for interaction effect (Jose, 2013); (Aiken, West, \& Reno, 1991) and to reduce the chances of multicollinearity. Also, the study assessed the same assumption using variance inflation factors (VIF). The VIF values provided that multicollinearity was not a major issue, as all the values were less than the recommended value of 10 (F. Hair Jr et al., 2014); (Stevens, 2012). The models for this study were specified as follows;

Model 1 below presents the equation for control variables:

$$
F I=\beta_{O}+\beta_{1} F S+\beta_{2} F A+\beta_{3} F P+\mathrm{e}
$$

The equation of the main effects is estimated as follows (Model 2):

$$
F I=\beta_{O}+\beta_{1} F S+\beta_{2} F A+\beta_{3} F P+\beta_{4} B M O+\beta_{5} B M I+\mathrm{e}
$$

The moderated model is estimated as follows (Model 3):

$$
F I=\beta_{O}+\beta_{1} F S+\beta_{2} F A+\beta_{3} F P+\beta_{4} B M O+\beta_{5} B M I+\beta_{6} C O+\beta_{7} B M O * C O+\beta_{8} B M I * C O+\mathrm{e}
$$

Where;

FI (Firm innovation); FS (Firm size); FA (Firm age); FP (Financial performance); BMO (Board member openness); BMI (Board member independence); CO (Chief executive officer Optimism).

\section{Results}

Table 1 presented the means, standard deviations, and correlation between all variables in the study. From the results, a significant correlation between board chairman self-efficacy, board member's expertise, CEO optimism, and firm innovation was reported. Except for financial performance, there was no significant correlation between firm size, age, and firm innovation.

Table 1 - Descriptive Statistics and Correlation Matrix

\begin{tabular}{cccccccccc} 
& $\mathbf{1}$ & $\mathbf{2}$ & $\mathbf{3}$ & $\mathbf{4}$ & $\mathbf{5}$ & $\mathbf{6}$ & $\mathbf{7}$ & Mean & $\boldsymbol{S D}$ \\
\hline 1 & 1 & & & & & & & 3.58 & .506 \\
2 & $.633^{* *}$ & 1 & & & & & & 3.71 & .707 \\
3 & $.608^{* *}$ & $.491^{* *}$ & 1 & & & & & 3.75 & .730 \\
4 & $.326^{* *}$ & $.402^{* *}$ & .153 & 1 & & & & .403 & .503 \\
5 & $.239^{* *}$ & .166 & .132 & .117 & 1 & & & 3.75 & .699 \\
6 & .109 & .069 & .026 & .045 & -.088 & 1 & & 1.82 & 1.462 \\
7 & -.137 & -.039 & -.033 & .043 & $-.206^{*}$ & $.181^{*}$ & 1 & 2.81 & .451 \\
\hline
\end{tabular}

** Correlation is significant at the 0.01 level (2-tailed), * Correlation is significant at the 0.05 level (2-tailed). Where: 1. Firm innovation, 2. Board Member's Openness, 3. Board member's independence, 4. CEO optimism, 5. Financial performance, 6. Firm size, 7. Firm age

\section{Testing of hypotheses}

First and foremost, all the control variables and dependent variable were regressed in Model 1. From Table 2, none of the variables were significant except financial performance. This implied that when financial institutions are more profitable, they are likely to have enough resources to engage in firm innovation. In Model 2, 
independent and control variables were modeled to test for $\mathrm{H}_{01}$ and $\mathrm{H}_{02}$. The final step in Model 3 was the analysis of the control, independent, moderator, and interaction terms between CEO optimism and predictor variables were performed to test for $\mathrm{H}_{03 a}$ and $\mathrm{H}_{03 \mathrm{~b}}$. A significant interaction term, as shown in Model 3 , indicates moderation since all the conditions of moderation were fully met by (Hayes, 2013). Therefore, the results for $\mathrm{H}_{\mathrm{o} 1}$ and $\mathrm{H}_{\mathrm{o} 2}$ are shown in Model 2. $\mathrm{H}_{\mathrm{o} 1}$ had proposed that board member's openness would positively affect firm innovation. The results showed that board member's openness had a positive and high significant effect on firm innovation $(\beta=.416, p<.05)$. Thus, the hypothesis was failed to be rejected. $H_{\mathrm{o} 2}$ had postulated that board members independence positively enhances firm innovation. The results indicated that board members independence positively and significantly influenced firm innovation $(\beta=.384, p<.05)$. Hence, the hypothesis was supported. Detailed results of the moderated regression analysis for $\mathrm{H}_{\mathrm{o} 3 \mathrm{a}}$ and $\mathrm{H}_{\mathrm{o} 3 \mathrm{~b}}$ are presented in Model 3. As displayed in Table 3, the interaction terms are all significant and indicate that CEO optimism positively and significantly moderates the relationship board member's openness and firm innovation $(\beta=.294, p<.01)$. On the contrary, it negatively and significantly moderates the relationship between board member's independence and firm innovation $(\beta=-.579, p<.01)$.

Table 2 - Regression Results

\begin{tabular}{lccc}
\hline & Model 1 & Model 2 & Model 3 \\
\hline Variables & $\mathrm{B}$ & $\mathrm{B}$ & $\mathrm{B}$ \\
(Constant) & $-.000(.085)$ & $-.000(.060)$ & $.021(.056)$ \\
Firm Size & $.151(.087)$ & $.099(.062)$ & $.090(.057)$ \\
Firm Age & $-.118(.088)$ & $-.104(.063)$ & $-.054(.059)$ \\
Financial Performance & $.228^{*}(.087)$ & $.107(.063)$ & $.152^{*}(.059)$ \\
Board Member's openness & & $.416^{* *}(.070)$ & $.113(.091)$ \\
Board Member's independence & & $.384^{* *}(.069)$ & $.739^{* *}(.139)$ \\
CEO Optimism & & & $.433^{* *}(.102)$ \\
Board Member's Openness*CEO Optimism & & & $.294^{*}(.092)$ \\
Board Member's independence*CEO Optimism & & & $-.579 *(.179)$ \\
Model Summary & .087 & .547 & .628 \\
$\mathrm{R}^{2}$ & .065 & .529 & .603 \\
Adjusted R ${ }^{2}$ & .087 & .460 & .081 \\
$\mathrm{R}^{2} \Delta$ & $4.014^{*}$ & $62.905^{* *}$ & $8.755^{* *}$ \\
F $\Delta$ & & & \\
\hline a Dependent Variable: Zscore (Firm Innovation) & $\mathrm{N}=130, * \mathrm{p}<0.05 . * * \mathrm{p}<0.01$, CEO - Chief Executive \\
Officer & & &
\end{tabular}

Following (Aiken et al., 1991) and (Jose, 2013), the mod graph was presented to help in the interpretation of the significant interaction terms in Figures 1 and 2. The high and low values of the predictor variables were used to construct the mod graphs, which depicts the form of moderation. As shown by the steepness of the slope in Figure 2, the effect of the board member's openness and firm innovation is enhanced when CEOs are overly optimistic; hence, $\mathrm{H}_{\mathrm{o} 3 a}$ was supported. This implies that when CEOs are highly optimistic, they tend to stimulate board members to be more open and willing to share ideas in their discussions on the board. The members can offer advice to the executives based on their private knowledge and information on the strategic decision such as to innovate. Thus, the influence of a board composed of directors who are open and generous in their suggestions on firm innovation is enhanced when CEO is highly optimistic because such CEOs exude confidence and attach value to achieving such a strategic activity. 


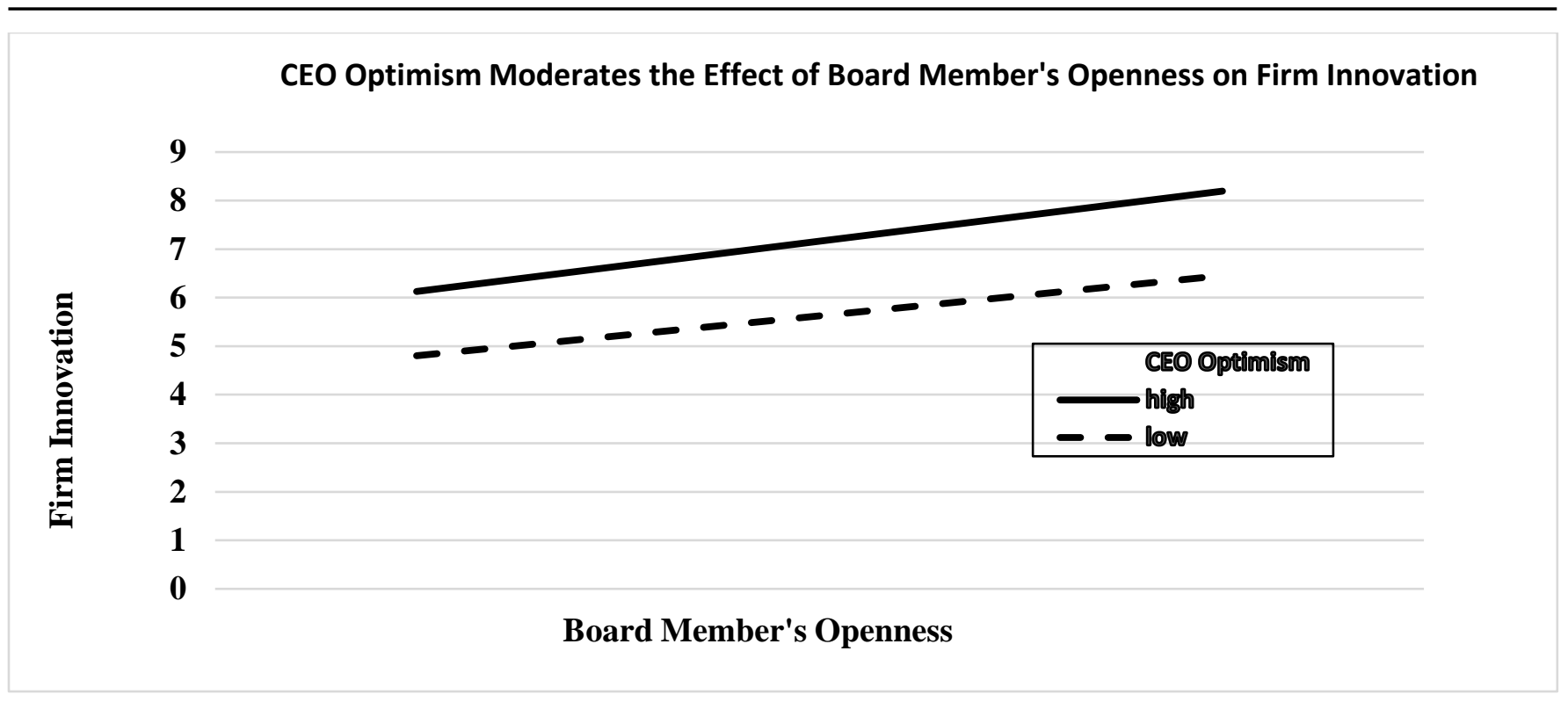

Figure 2 - The effect of board member's openness on firm innovation under different levels of CEO optimism

The interaction effect of CEO optimism decreased with the contribution of the board member's independence, as shown by the negative steepness of the slope in Figure 3. This suggested that board members who are likely to be risk-averse when the CEO is overly optimistic. Consequently, as a result of the risk attitude, they might not be supportive of innovation proposals initiated by highly optimistic CEOs. So, the effect of board members independence on firm innovation reduces when the CEO is highly optimistic.

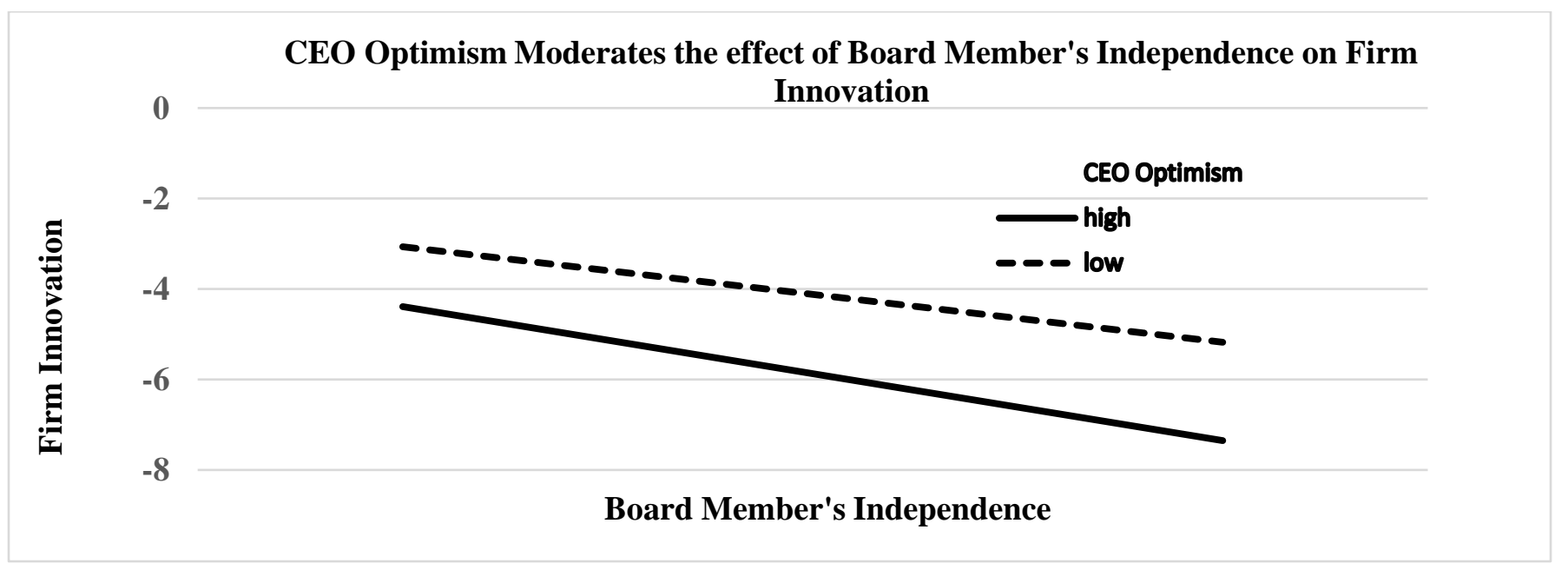

Figure 3 - The effect of board member's independence on firm innovation under different levels of CEO optimism

\section{Discussion}

Following the resource dependence and optimism theories, this study examined an important trait; CEO optimism on whether it moderates the nexus between board leadership and firm innovation in the financial sector in Kenya. This study found that a board member's openness and independence are key competencies needed for firm innovation in a firm. First, the regression results of this study are consistent with the findings of (Charan, 2005) and (Leblanc \& Gillies, 2005) that open interchange and interactions among the different directors of diverse background may be an effective way through which ideas could be generated for innovation. 
Equally, the findings are in agreement with the proposition that a board with members who are open and willing to share ideas have a wider perspective. This willingness can change the way firms operate and are sensitive to changes in the business environment with the ability to decipher and advice the firm on how to be innovative in their activities (Sun et al., 2015). Thus, based on the resource dependence view (Pfeffer \& Salancik, 1978), openness among the board members is a key resource that acts as a conduit to generate unique information that may be transformed into real products or services in the firm.

Secondly, the regression results found that board members independence significantly enhance firm innovation in financial institutions. These findings are consistent with the works of the previous scholars that independence of the directors enhance firm innovation (Oh \& Barker III, 2018); (Balsmeier et al., 2017); (Helmers et al., 2017); (Sena, Duygun, Lubrano, Marra, \& Shaban, 2018); (Lu \& Wang, 2018); (Jiraporn, Lee, Park, \& Song, 2018). Because of the board of directors are independent of the firm, they can prioritize innovation proposals as it would improve firm competitiveness and survival. Similarly, the results of the study confirm that directors have different risk perceptions (Hoskisson, Hitt, Johnson, \& Grossman, 2002) and thus would make decisively and carefully evaluate the practicality of the innovation proposals. More importantly, they are custodians of innovations and offer valuable resources supportive of such innovations (Chen, 2014) because they can link the firm and its environment to secure collaboration and commitment of other resourceful institutions and partners (Pfeffer \& Salancik, 1978; (Hillman, Cannella, \& Paetzold, 2000).

Also, the moderated regression results showed that CEO optimism is an important trait that influences strategic outcomes such as innovation. We show that CEO optimism influence board members to be more open in terms of the views and suggestions they do give in board deliberations because CEOs who are optimistic tend to envision greater opportunities for the firm (Levinthal \& March, 1993). When CEOs are overly optimistic, they tend to be futuristic and exude confidence that the set goals would be achievable. Hence, this way board members who are open are likely to create a room for ideas and as a result can advise based on their private knowledge. It was thus concluded that CEO optimism is key for strategic board decisions such as firm innovation.

Furthermore, the results indicated that CEO optimism negatively moderates the link between board member's independence and firm innovation. Although the board of directors brings unbiased assessments and objectivity in the boardroom, their strict monitoring role may restrain firm innovation by instilling fear of being castigated as a result of unsuccessful innovations and may lead to CEOs to be reluctant to expend their efforts on innovation (Manso, 2011). Besides, overly optimistic CEOs overestimate their expectations (Zhao \& Ziebart, 2017), especially on certain strategic functions such as innovation. Because of high expectations they are likely to ignore existing market developments (Langabeer \& DelliFraine, 2011) that could or hinder innovation. Consequently, as custodians of innovation, board members who are risk-averse (Kor, 2006) to support innovations because of different risk awareness. Therefore, the negative interaction effect of CEO optimism on the relationship between board independence and firm innovation is attributed to the notion that when CEOs are highly optimistic, they look every situation from a positive outlook which may not be the case with directors who are independent. This is so because directors who are independent are likely to do an in-depth information search that might refrain them from putting much more efforts on innovation. This in itself may frustrate CEOs who are highly optimistic hence the negative effect.

\section{Conclusion}

First, the findings agreed with the resource dependence theory, that board of directors are providers of crucial resources that includes their openness and independence other than strategic guidance and advice that are core to firm innovation. The results confirm that the openness and independence among board members on the board are important aspects of leadership that are useful for innovation. Since financial institutions operate in 
the dynamic and competitive business environment, openness, and interactions among board members on the board are key because it is out these competencies that ideas that support firm innovations. Moreover, the study extends knowledge to theory and literature by studying how board member's openness and independence enhance firm innovation.

The findings suggested that CEO optimism plays a vital role in board leadership and firm innovation relationship. The results offer an in-depth understanding of how CEO optimism affect strategic decisions of the board. Generally, the ownership and governance structure of firms in the financial sector is guided by wellestablished regulations, and ordinarily, the CEO may not be the founder and sole decision-maker as opposed to private firms which are closely held. This positions the board members as central to a firm's strategic decision-making where they approve agendas aligned to the goals of the firm. More importantly, for this to be achieved, the CEO and other board members must work together to ensure that their firms remain competitive and sustainable. It was argued that optimism establishes the CEO as a catalyst in those decisions that would inspire and make the board to confidently use their proficiencies to become innovative.

About practical and policy implications, the findings of this study suggested that board chairman self-efficacy is a key aspect that enhances firm innovation. As such, it is inherent for firms to appoint board members who are more open and independent in strategic decision making to be innovative. Also, if financial institutions are to realize innovation gains from the board, then such boards should consider hiring an optimistic CEO.

The research study was not without limitations, some of which may provide an opportunity for future research. First, the study focused only on a few board leadership aspects to examine the relationship between the board and innovation. Other factors such as background, age, gender, education such as technology and human capital of the chairman may be studied in the future. Second, future studies may examine the influence of other traits such as CEO narcissism, humility, and transformational leadership onboard leadership - innovation relationship.

Funding: This research received no external funding.

Acknowledgments: We acknowledge the contribution and the scholarly support from Moi University, School of Business, and Economics.

Conflicts of Interest: The authors declare no conflict of interest.

\section{References}

Abebe, M., \& Myint, P. P. A. (2018). Board characteristics and the likelihood of business model innovation adoption: evidence from the smart home industry. International Journal of Innovation Management, 22(01), 1850006.

Adams, R. B., \& Ferreira, D. (2007). A theory of friendly boards. The journal of finance, 62(1), 217-250.

Aiken, L. S., West, S. G., \& Reno, R. R. (1991). Multiple regression: Testing and interpreting interactions: Sage.

Anderloni, L., Llewellyn, D. T., \& Schmidt, R. H. (2009). Financial innovation in retail and corporate banking: Edward Elgar Publishing.

Anderson, R. C., \& Reeb, D. M. (2003). Founding-family ownership and firm performance: evidence from the S\&P 500. The journal of finance, 58(3), 1301-1328.

Balsmeier, B., Fleming, L., \& Manso, G. (2017). Independent boards and innovation. Journal of Financial Economics, 123(3), 536-557.

Brown, W. A. (2005). Exploring the association between board and organizational performance in nonprofit organizations. Nonprofit Management and Leadership, 15(3), 317-339. 
Calantone, R. J., Cavusgil, S. T., \& Zhao, Y. (2002). Learning orientation, firm innovation capability, and firm performance. Industrial marketing management, 31(6), 515-524.

Capozzi, M. M. (2010). Leadership and innovation. Development Outreach, 12(1), 25-28.

Carver, C. S., \& Scheier, M. F. (2014). Dispositional optimism. Trends in cognitive sciences, 18(6), 293-299.

Charan, R. (2005). Ending the CEO succession crisis. Harvard business review, 83(2), 72-81.

Charan, R., Carey, D., \& Useem, M. (2013). Boards that lead: When to take charge, when to partner, and when to stay out of the way: Harvard Business Review Press.

Chatterjee, A., \& Hambrick, D. C. (2007). It's all about me: Narcissistic chief executive officers and their effects on company strategy and performance. Administrative science quarterly, 52(3), 351-386.

Chatterjee, A., \& Hambrick, D. C. (2011). Executive personality, capability cues, and risk taking: How narcissistic CEOs react to their successes and stumbles. Administrative science quarterly, 56(2), 202-237.

Chen, H. L. (2014). Board capital, CEO power and R\&D investment in electronics firms. Corporate Governance: An International Review, 22(5), 422-436.

Chiesi, F., Galli, S., Primi, C., Innocenti Borgi, P., \& Bonacchi, A. (2013). The Accuracy of the Life Orientation Test-Revised (LOT-R) in measuring dispositional optimism: Evidence from item response theory analyses. Journal of personality assessment, 95(5), 523-529.

Chipeta, C., \& Muthinja, M. M. (2018). Financial innovations and bank performance in Kenya: Evidence from branchless banking models. South African Journal of Economic and Management Sciences, 21(1), 1-11.

Cohen, L., Diether, K., \& Malloy, C. (2013). Misvaluing innovation. The Review of Financial Studies, 26(3), 635666.

Daily, C. M., Dalton, D. R., \& Cannella Jr, A. A. (2003). Corporate governance: Decades of dialogue and data. Academy of management review, 28(3), 371-382.

Dalziel, T., Gentry, R. J., \& Bowerman, M. (2011). An integrated agency-resource dependence view of the influence of directors' human and relational capital on firms' R\&D spending. Journal of Management Studies, 48(6), 1217-1242.

Deschamps, J.-P., \& Nelson, B. (2014). Innovation governance: How top management organizes and mobilizes for innovation: John Wiley \& Sons.

Drees, J. M., \& Heugens, P. P. (2013). Synthesizing and extending resource dependence theory: A metaanalysis. Journal of Management, 39(6), 1666-1698.

Dutta, S., Lanvin, B., \& Wunsch-Vincent, S. (2018). The Global Innovation Index, 2018: Ithaca, NY: Cornell, INSEAD, \& WIPO.

F. Hair Jr, J., Sarstedt, M., Hopkins, L., \& G. Kuppelwieser, V. (2014). Partial least squares structural equation modeling (PLS-SEM) An emerging tool in business research. European Business Review, 26(2), 106-121.

Faleye, O., Hoitash, R., \& Hoitash, U. (2011). The costs of intense board monitoring. Journal of Financial Economics, 101(1), 160-181.

Fama, E. F., \& Jensen, M. C. (1983). Separation of ownership and control. The journal of law and Economics, 26(2), 301-325.

Finkelstein, S. (1992). Power in top management teams: Dimensions, measurement, and validation. Academy of Management journal, 35(3), 505-538.

Finkelstein, S., Cannella, S. F. B., Hambrick, D. C., \& Cannella, A. A. (2009). Strategic leadership: Theory and research on executives, top management teams, and boards: Oxford University Press, USA.

Flynn, B. B., Huo, B., \& Zhao, X. (2010). The impact of supply chain integration on performance: A contingency and configuration approach. Journal of operations management, 28(1), 58-71.

Forbes, D. P., \& Milliken, F. J. (1999). Cognition and corporate governance: Understanding boards of directors as strategic decision-making groups. Academy of management review, 24(3), 489-505.

Gabrielsson, J., \& Huse, M. (2005). Outside directors in SME boards: a call for theoretical reflections. Corporate Board: role, duties and composition, 1(1), 28-37. 
Gabrielsson, J., Huse, M., \& Minichilli, A. (2007). Understanding the leadership role of the board chairperson through a team production approach. International journal of leadership studies, 3(1), 21-39.

Gallagher, M. W., \& Lopez, S. J. (2009). Positive expectancies and mental health: Identifying the unique contributions of hope and optimism. The Journal of Positive Psychology, 4(6), 548-556.

Giorgis Sahile, S. W., Tarus, D. K., \& Cheruiyot, T. K. (2015). Market structure-performance hypothesis in Kenyan banking industry. International Journal of Emerging Markets, 10(4), 697-710.

Graham, J. R., Harvey, C. R., \& Puri, M. (2013). Managerial attitudes and corporate actions. Journal of Financial Economics, 109(1), 103-121.

Hambrick, D. C. (2007). Upper echelons theory: An update: Academy of Management Briarcliff Manor, NY 10510.

Harpaz-Itay, Y., \& Kaniel, S. (2012). Optimism versus pessimism and academic achievement evaluation. Gifted Education International, 28(3), 267-280.

Hayes, A. F. (2013). Introduction to mediation, moderation, and conditional process analysis: Methodology in the Social Sciences. Kindle Edition, 193.

Haynes, K. T., \& Hillman, A. (2010). The effect of board capital and CEO power on strategic change. Strategic Management Journal, 31(11), 1145-1163.

Helmers, C., Patnam, M., \& Rau, P. R. (2017). Do board interlocks increase innovation? Evidence from a corporate governance reform in India. Journal of Banking \& Finance, 80, 51-70.

Hillman, A. J., Cannella, A. A., \& Paetzold, R. L. (2000). The resource dependence role of corporate directors: Strategic adaptation of board composition in response to environmental change. Journal of Management Studies, 37(2), 235-256.

Hillman, A. J., \& Dalziel, T. (2003). Boards of directors and firm performance: Integrating agency and resource dependence perspectives. Academy of management review, 28(3), 383-396.

Hogan, R., \& Kaiser, R. B. (2005). What we know about leadership. Review of general psychology, 9(2), 169-180.

Hoskisson, R. E., Hitt, M. A., Johnson, R. A., \& Grossman, W. (2002). Conflicting voices: The effects of institutional ownership heterogeneity and internal governance on corporate innovation strategies. Academy of Management journal, 45(4), 697-716.

Hughes, N., \& Lonie, S. (2007). M-PESA: mobile money for the "unbanked" turning cellphones into 24-hour tellers in Kenya. Innovations: technology, governance, globalization, 2(1-2), 63-81.

Huse, M. (2005). Accountability and creating accountability: A framework for exploring behavioural perspectives of corporate governance. British journal of management, 16, S65-S79.

Iren, P., \& Tee, K. (2018). Boardroom Diversity and Innovation in the UAE Banks. International Journal of Innovation Management, 22(03), 1850029.

Jack, W., \& Suri, T. (2011). Mobile money: The economics of M-PESA: National Bureau of Economic Research.

Jack, W., \& Suri, T. (2014). Risk sharing and transactions costs: Evidence from Kenya's mobile money revolution. American Economic Review, 104(1), 183-223.

Jehn, K. A. (1995). A multimethod examination of the benefits and detriments of intragroup conflict. Administrative science quarterly, 256-282.

Jiang, J., Wang, S., \& Zhao, S. (2012). Does HRM facilitate employee creativity and organizational innovation? A study of Chinese firms. The International Journal of Human Resource Management, 23(19), 4025-4047.

Jiraporn, P., Lee, S. M., Park, K. J., \& Song, H. (2018). How do independent directors influence innovation productivity? A quasi-natural experiment. Applied Economics Letters, 25(7), 435-441.

Jose, P. E. (2013). Doing statistical mediation and moderation: Guilford Press.

Khraisha, T., \& Arthur, K. (2018). Can we have a general theory of financial innovation processes? A conceptual review. Financial Innovation, 4(1), 4. 
Kimenyi, M., Mwega, F. M., \& Ndung'u, N. (2015). The African lions: Kenya country case study: WIDER Working Paper.

Kor, Y. Y. (2006). Direct and interaction effects of top management team and board compositions on R\&D investment strategy. Strategic Management Journal, 27(11), 1081-1099.

Langabeer, J. R., \& DelliFraine, J. (2011). Does CEO optimism affect strategic process? Management Research Review, 34(8), 857-868.

Langabeer, J. R., \& Yao, E. (2012). The impact of chief executive officer optimism on hospital strategic decision making. Health care management review, 37(4), 310-319.

Lashitew, A. A., van Tulder, R., \& Liasse, Y. (2019). Mobile phones for financial inclusion: What explains the diffusion of mobile money innovations? Research Policy, 48(5), 1201-1215.

Leblanc, R., \& Gillies, J. (2005). Inside the boardroom: How boards really work and the coming revolution in corporate governance: John Wiley \& Sons.

Lepoutre, J., \& Oguntoye, A. (2018). The (non-) emergence of mobile money systems in Sub-Saharan Africa: A comparative multilevel perspective of Kenya and Nigeria. Technological Forecasting and Social Change, 131, 262-275.

Lerner, J., \& Tufano, P. (2011). The consequences of financial innovation: a counterfactual research agenda. Annu. Rev. Financ. Econ., 3(1), 41-85.

Levinthal, D. A., \& March, J. G. (1993). The myopia of learning. Strategic Management Journal, 14(S2), 95-112.

Li, Y.-H., Huang, J.-W., \& Tsai, M.-T. (2009). Entrepreneurial orientation and firm performance: The role of knowledge creation process. Industrial marketing management, 38(4), 440-449.

Lin, H.-F. (2007). Knowledge sharing and firm innovation capability: an empirical study. International Journal of manpower, 28(3/4), 315-332.

Lu, J., \& Wang, W. (2018). Managerial conservatism, board independence and corporate innovation. Journal of Corporate Finance, 48, 1-16.

Makri, M., \& Scandura, T. A. (2010). Exploring the effects of creative CEO leadership on innovation in hightechnology firms. The Leadership Quarterly, 21(1), 75-88.

Manso, G. (2011). Motivating innovation. The journal of finance, 66(5), 1823-1860.

Merton, R. C. (1995). Financial innovation and the management and regulation of financial institutions. Journal of Banking \& Finance, 19(3-4), 461-481.

Munyegera, G. K., \& Matsumoto, T. (2016). Mobile money, remittances, and household welfare: panel evidence from rural Uganda. World Development, 79, 127-137.

Muthiora, B. (2015). Enabling mobile money policies in Kenya: Fostering a digital financial revolution. GSMA Mobile Money for the Unbanked.

Ngugi, B., Pelowski, M., \& Ogembo, J. G. (2010). M-pesa: A Case Study of the Critical Early Adopters' Role in the Rapid Adoption of Mobile Money Banking in Kenya. The Electronic Journal of Information Systems in Developing Countries, 43(1), 1-16.

Nicholson, G. J., \& Kiel, G. C. (2004). A framework for diagnosing board effectiveness. Corporate Governance: An International Review, 12(4), 442-460.

Oh, W.-Y., \& Barker III, V. L. (2018). Not all ties are equal: CEO outside directorships and strategic imitation in R\&D investment. Journal of Management, 44(4), 1312-1337.

Pfeffer, J., \& Salancik, G. R. (1978). The extemal control of organizations. A Resource Dependence Perspective, New York et al.: Harper \& Row.

Pfeffer, J., \& Salancik, G. R. (2003). The external control of organizations: A resource dependence perspective: Stanford University Press.

Pugliese, A., Minichilli, A., \& Zattoni, A. (2014). Integrating agency and resource dependence theory: Firm profitability, industry regulation, and board task performance. Journal of Business Research, 67(6), 11891200. 
Reguera-Alvarado, N., \& Bravo, F. (2018). The impact of directors' high-tech experience on innovation in low-tech firms. Innovation, 20(3), 223-239.

Scheier, M. F., \& Carver, C. S. (1985). Optimism, coping, and health: assessment and implications of generalized outcome expectancies. Health psychology, 4(3), 219.

Scheier, M. F., Carver, C. S., \& Bridges, M. W. (1994). Distinguishing optimism from neuroticism (and trait anxiety, self-mastery, and self-esteem): a reevaluation of the Life Orientation Test. Journal of personality and social psychology, 67(6), 1063.

Sekaran, U., \& Bougie, R. (2013). Edisi 6. Research Methods for Business.

Seligman, M. E. (2006). Learned optimism: How to change your mind and your life: Vintage.

Sellevold, T., Huse, M., \& Hansen, C. (2007). The value creating board: results from the" Follow-up surveys" 2005/2006 in Norwegian firms.

Sena, V., Duygun, M., Lubrano, G., Marra, M., \& Shaban, M. (2018). Board independence, corruption and innovation. Some evidence on UK subsidiaries. Journal of Corporate Finance, 50, 22-43.

Sonnenfeld, J. A. (2002). What makes great boards great. Harvard business review, 80(9), 106-113.

Stevens, J. P. (2012). Applied multivariate statistics for the social sciences: Routledge.

Sun, S. L., Zhu, J., \& Ye, K. (2015). Board openness during an economic crisis. Journal of Business Ethics, 129(2), 363-377.

Sunder, J., Sunder, S. V., \& Zhang, J. (2017). Pilot CEOs and corporate innovation. Journal of Financial Economics, 123(1), 209-224.

Tarus, D. K., \& Sitienei, E. K. (2015). Intellectual capital and innovativeness in software development firms: the moderating role of firm size. Journal of African Business, 16(1-2), 48-65.

Trevelyan, R. (2008). Optimism, overconfidence and entrepreneurial activity. Management Decision, 46(7), 9861001.

Tuwey, J. K., \& Tarus, D. K. (2016). Does CEO power moderate the relationship between board leadership and strategy involvement in private firms? Evidence from Kenya. Corporate Governance: The International Journal of Business in Society, 16(5), 906-922.

Wang, P. (2009). An integrative framework for understanding the innovation ecosystem. Advancing the Study of Innovation and Globalization in Organizations.

Weill, P., \& Ross, J. W. (2004). IT governance: How top performers manage IT decision rights for superior results: Harvard Business Press.

Xie, X., \& O'Neill, H. (2013). Boards as resource providers and monitors for research and development. Journal of Business Strategies, $30(2), 180$.

Yar Hamidi, D., \& Gabrielsson, J. (2014). Developments and trends in research on board leadership: a systematic literature review. International Journal of Business Governance and Ethics, 9(3), 243-268.

Zhang, H., Ou, A. Y., Tsui, A. S., \& Wang, H. (2017). CEO humility, narcissism and firm innovation: A paradox perspective on CEO traits. The Leadership Quarterly, 28(5), 585-604.

Zhao, Q., \& Ziebart, D. (2017). Consequences of CEO Overconfidence. Accounting and Finance Research, 6(2), 94-113. 